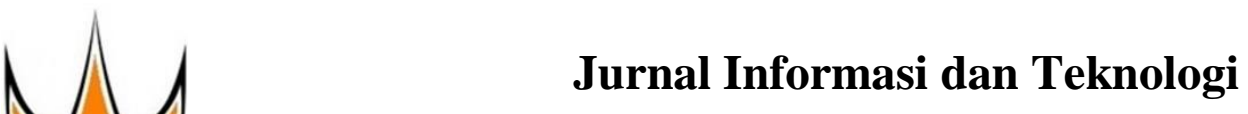

http://www.jidt.org

2021 Vol. $3 \quad$ No. $4 \quad$ Hal: $251-256$

e-ISSN: 2714-9730

\title{
Prediksi Tingkat Produksi Buah Kelapa Sawit dengan Metode Single Moving Average
}

\author{
Feri Irawan $^{1 \bowtie}$, Sumijan $^{2}$, Yuhandri $^{3}$ \\ ${ }^{1,2,3}$ Universitas Putra Indonesia YPTK Padang \\ fery . irawan1922@gmai 1.com
}

\begin{abstract}
Palm oil is one of the largest agricultural products in Indonesia and has a high economic value and can improve the welfare of oil palm farmers. The amount of oil palm fruit production is not always stable or increasing, but increases up and down which is influenced by many factors. This study aims to estimate the average amount of oil palm fruit production every year and prepare anticipatory steps in the event of a decrease in oil palm fruit production. The image processed in this study was the production of palm fruit in a few years which was generated from the results of oil palm plantations. Furthermore, data is processed using the Single Moving Avarage method. This method is a method of forecasting or predictions using a number of actual data to generate predictive values in the future. The results of testing on the single moving average method can be seen forecasts of oil palm fruit production in 2021 using Moving Averge 3 of 200.749 tons with Mean Absolute Deviation 19.604, Mean Squared Error 456.963.281 and Mean Absolute Percent Error 10,0\%. Moving Averge 4 was 206.771 tons with the Mean Absolute Deviation 27.333, Mean Squared Error 752.202.579 and Mean Absolute Percent Error 14,2\%. Moving Averge 5 was 210.908 tons with Mean Absolute Deviation 26.890, Mean Squared Error 723.072.100 and Mean Absolute Percent Error $14.1 \%$. The test results using the Single Moving Average method can be concluded that forecasting using Moving Average 3 can be used because the relative error level is smaller than Moving Average 4 and 5, with the value of the Mean Absolute Percent error of $10.0 \%$ and Mean Absolute Deviation 19.604.
\end{abstract}

Keywords: Palm Oil, Forcasting, Moving Average, MSE, MAPE.

\begin{abstract}
Abstrak
Kelapa sawit merupakan salah satu hasil pertanian terbesar yang ada di indonesia dan memiliki nilai ekonomi yang tinggi dan dapat meningkatkan kesejahteraan para petani sawit. Jumlah produksi buah kelapa sawit tidak selalu stabil atau meningkat, melainkan mengalami naik turun yang dipengaruhi oleh banyak faktor. Penelitian ini bertujuan untuk memperkirakan jumlah rata-rata produksi buah kelapa sawit setiap tahun dan mempersiapkan langkah antisipasi apabila terjadi penurunan produksi buah kelapa sawit. Citra yang diolah dalam penelitian ini adalah produksi buah sawit dalam beberapa tahun terkhir yang bersumber dari hasil kebun kelapa sawit. Selanjutnya, data diolah menggunakan metode single moving avarage. Metode ini merupakan metode peramalan atau prediksi dengan menggunakan sejumlah data yang aktual untuk membangkitkan nilai prediksi dimasa yang akan datang. Hasil dari pengujian terhadap metode single moving average ini dapat dilihat perkiraan produksi buah kelapa sawit pada tahun 2021 menggunakan Moving Averge 3 sebanyak 200.749 Ton dengan Mean Absolute Deviation 19.604, Mean Squared Error 456.963.281 dan Mean Absolute Percent Error 10,0\%. Moving Averge 4 sebanyak 206.771 Ton dengan Mean Absolute Deviation 27.333, Mean Squared Error 752.202.579 dan Mean Absolute Percent Error 14,2\%. Moving Averge 5 sebanyak 210.908 Ton dengan Mean Absolute Deviation 26.890, Mean Squared Error 723.072.100 dan Mean Absolute Percent Error 14.1\%. Hasil pengujian menggunakan metode Single Moving Average dapat disimpulkan bahwa Peramalan menggunakan Moving Average 3 dapat digunakan karena tingkat erorr yang relative lebih kecil dibanding Moving Average 4 dan 5, dengan nilai Mean Absolute Percent Error 10,0\% dan Mean Absolute Deviation 19.604.
\end{abstract}

Kata kunci: Kelapa Sawit, Peramalan, Rata-Rata Bergerak, MSE, MAPE

(C) $2021 \mathrm{JIdT}$

\section{Pendahuluan}

Negara Indonesia merupakan negara yang memiliki keunggulan dalam bidang pertanian, dimana Indonesia memiliki perkebunan dan pertanian terbesar di ASEAN. Jumlah produksi perkebunan sawit di Indonesia pada tahun 2016 adalah 33,23 juta ton, yang dihasilkan dari 11,91 juta $\mathrm{Ha}$ luas total areal perkebunan kelapa sawit secara nasional [1]. Dari perkebunan inilah Indonesia dapat menghasilkan komoditi ekspor terbesar didunia [2]. Kelapa sawit juga Metode peramalan secara kuantitaif dapat dibagi menduduki posisi penting dalam pertanian dan menjadi dua jenis metode peramalan, yaitu model deret perkebunan di indonesia. Hal ini dikarenakan tanaman waktu (time series) dan model regresi (regression). kelapa sawit tergolong tanaman yang mudah Metode time series terdiri dari beberapa metode, salah perawatanya dan nilai jual yang relatif tinggi. Kelapa sawit banyak mengandung minyak nabati dan hidup di iklim tropis [3]. Produktivitas kelapa sawit setiap bulan tidak selalu stabil, tetapi mengalami naik-turun yang dipengaruhi oleh banyak faktor, seperti iklim, curah hujan, kesuburan tanah, maka perlu dilakukan pemeliharaan yang intensif [4]. Langkah-langkah antisipasi seperti pemberian pupuk dapat dilakukan dengan mengamati pola hasil produksi.

Diterima: 17-08-2021 | Revisi: 01-10-2021 | Diterbitkan: 31-12-20121| doi: 10.37034/jidt.v3i4.162 
satunya adalah moving average forecasting atau rata- (exponential smooting) dan 262.899 (trend analysis) rata bergerak [5]. Penentuan metode dari time series dimana dalam penelitian ini metode trend analysis perlu diketahui pola dari data, sehingga peramalan memiliki nilai error yang lebih kecil dengan nilai menggunakan metode yang sesuai dengan pola data masing-masing secara berurutan MAD 14.716,12, dapat dilakukan. Pola data sendiri dapat dibedakan MSE 327.282.084,17 dan MAPE 0,09 [15].

menjadi empat jenis, yaitu musiman, siklus, trend, dan irregular [6]. Peramalan adalah seni atau ilmu memperkirakan masa depan. Hal ini dapat dilakukan Metodologi penelitian ini akan dijelaskan beberapa dengan melibatkan pengambilan data historis dan tahapan metode yang akan digunakan sehingga dapat memproyeksikan kemasa yang akan datang dengan mengatasi permasalahan pada saat ini. Metodologi suatu model yang sistematis. Atau bisa juga merupakan langkah-langkah atau kerangka kerja yang menggunkan kombinasi model matematis dengan dimaksudkan untuk mengerjakan penelitian dengan pertimbangan yang baik [7]. Metode peramalan yang cara-cara tertentu untuk memperoleh hasil yang digunakan yaitu metode single moving average. maksimal. Adapun kerangkan kerja penelitian ini dapat Metode ini adalah metode peramalan yang dilihat pada Gambar 1.

menggunakan sejumlah data aktual produksi sebelumnya untuk membangkitkan nilai ramalan dimasa yang akan datang [8]. Metode Single Moving Average mempunyai karakteristik khusus yaitu untuk menentukan ramalan pada periode yang akan datang memerlukan data historis selama jangka waktu tertentu. Selain itu, semakin panjang jangka waktu single moving average, efek pelicinan semakin terlihat dalam ramalan atau menghasilakan moving average yang semakin halus [9]. Dalam metode Single Moving Average terdapat beberapa metode penghitungan akurasi forecasting, seperti Mean Absolute Deviation (MAD), Mean Squre Error (MSE), dan Mean Absolute Percent Error (MAPE) [10]. Tujuan dilakukannya peramalan rata-rata bergerak tunggal adalah untuk menghilangkan atau mengurangi acakan (random ness) dalam deret waktu [11].

Forecasting (peramalan) merupakan alat bantu yang penting dalam perencanaan yang efektif dan efisien khususnya dalam bidang ekonomi [12]. Fungsi peramalan merupakan satu dari lima peran penting data mining (penggalian data). Data mining berkenaan dengan proses penggalian informasi tersembunyi dalam suatu basis data yang besar sehingga dapat memfasilitasi penemuan informasi yang tersembunyi dan penting dibalik basis data yang jumlah datanya sangat besar [13].

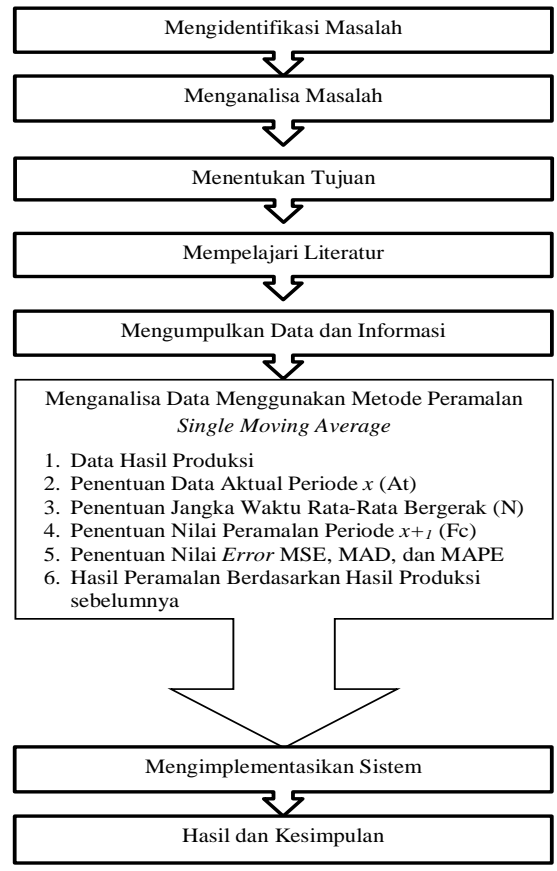

Gambar 1. Kerangka Kerja Penelitian

Berdasarkan kerangka kerja penelitian pada Gambar 1, peneliti menguraikan tahapan-tahapan dari kerangka kerja penelitian sebagai berikut:

Penerapan metode single moving average ini salah 2.1 Mengidentifikasi Masalah satunya oleh Aprilianti, dkk. (2020) dimana dilakukan penelitian peramalan permintaan produk sale pisang, menggunakan history permintaan dari bulan maret 2019 sampai desember 2020, dengan nilai peramalan sebanyak 12.7444 bungkus dan Mean Absolute Error 1.639 dan Mean Squared 7.658. hal ini menunjukan bahwa permintaan sale pisang mengalami penurunan dari periode sebelumnya [14]. Selanjutnya penelitian oleh Jaya (2019) tentang Peramalan Jumlah Populasi Sapi Potong di Kalimantan Selatan Menggunakan Metode Moving Average, Exponential Smoothing dan Trend Analysis dimana pada penelitian ini dilakukan perbandingan antara 3 metode dengan proyeksi populasi sapi potong pada tahun 2019 (periode berikutnya) adalah: 195.100 (moving average), 218.225

Tahapan identifikasi masalah merupakan suatu tahapan awal dalam penelitian. Peneliti melakukan perumusan masalah dari masalah yang ditemukan pada data hasil produksi kelapa sawit dan memberikan batasan dari permasalahan yang akan diteliti agar lebih terarah.

\subsection{Menganalisa Masalah}

Tahapan analisa masalah ini merupakan suatu tahapan yang dilakukan untuk dapat memahami masalah yang telah ditentukan dalam ruang lingkup atau batasan masalah dalam penelitian. Peneliti diharapkan dapat memahami masalah yang telah ditentukan tersebut dengan baik. Pada analisa masalah ini digambarkan proses untuk meramalkan jumlah produksi buah kelapa sawit yang akan datang. 


\subsection{Menentukan Tujuan Penelitian}

Pada tahapan ini dikemukakan tujuan yang ingin dicapai melalui proses penelitian. Tujuan penelitian harus jelas dan tegas. Tujuan penelitian adalah suatu target yang akan dicapai untuk mengatasi masalahmasalah yang ada.

\subsection{Mempelajari Literatur}

Tahapan mempelajari literatur ini sangat penting dilakukan agar mempunyai landasan baik secara teoritis yang benar dan dijelaskan oleh para peneliti dan ahli sebelumnya. Kemudian literatur-literatur yang dipelajari tersebut diseleksi dan dipilih literatur mana yang akan digunakan dalam penelitian. Literatur yang diambil dari berbagai sumber yaitu berupa buku, artikel, jurnal ilmiah tentang Peramalan serta bahan bacaan lain yang mendukung.

\subsection{Mengumpulkan Data dan Informasi}

Pengumpulan data dilakukan agar dapat memperoleh informasi sehingga tujuan dari penelitian menggunakan Metode Single Moving Average ini dapat tercapai. Pengumpulan data dengan melakukan observasi langsung di Usaha Dagang Anang. Pengamatan secara langsung dilokasi penelitian untuk melihat data yang akan diproses dan data yang diambil merupakan data hasil Produksi buah kelapa sawit sebelumnya.

\subsection{Melakukan Analisa Data}

Agar permasalahan penelitian ini dapat dianalisa maka digunakan Metode Peramalan Single Moving Average untuk dilakukan peramalan jumlah hasil produksi. Sebelum data dilakukan pengolahan, Harus dilakukan tahapan sebagai berikut :

\section{a. Data hasil produksi}

Pada tahap ini data hasil produksi yang akan diolah merupakan data hasil produksi sebelumnya, kemudian di olah hingga menjadi data yang valid.

b. Penentuan Data Aktual Periode $x(\mathrm{At})$

Langkah ini dengan menentukan data aktual periode. Data aktual periode ini adalah data hasil produksi kelapa sawit yang digunakan 6 tahun terakhir dari tahun 2015 sampai dengan 2020.

\section{c. Penentuan Jangka Waktu Rata-Rata Bergerak (N)}

Pada metode ini untuk penentuan jangka waktu ratarata bergerak menggunakan data paling sedikit 3 periode, tetapi yang sering digunakan antara lain 3, 4 dan 5 periode.

\section{d. Penentuan Nilai Peramalan Periode $(\mathrm{Fc})$}

Tahapan ini dengan menentukan hasil pengolahan data yang di ambil dari tahun sebelumya untuk menentukan di masa yang akan datang menggunakan metode Single Moving Average.

e. Penentuan Nilai Error MSE, MAD, dan MAPE
Tahapan ini dengan menghitung error dari hasil prediksi menggunakan rumus Mean Squared Error (MSE), Mean Absolute Deviation (MAD), dan Mean Absolute Percentage Error (MAPE).

\subsection{Mengimplementasikan Sistem}

Pada tahap ini implementasi dilakukan untuk mendapatkan pola terbaik dalam penelitian untuk menentukan Peramalan dimasa yang akan datang dengan data yang sudah diolah menggunakan Motode Single Moving Average.

\subsection{Hasil dan Kesimpulan}

Pada tahapan ini akan dilakukan analisa data yang dihasilkan dari metode Single Moving Average sehingga akan didapatkan hasil peramalan jumlah produksi untuk tahun berikutnya dengan cepat dan tepat. Hasil dan pembahasan ini merupakan bagian akhir dari penelitian.

\section{Hasil Dan Pembahasan}

\subsection{Tahapan Analisa dan Perancangan}

Pada tahapan ini dibahas mengenai analisa dan perancangan sistem secara terstruktur sehingga mengetahui keakuratan Metode Single Moving Average. Sistem yang akan dibangun berupa sistem Prediksi untuk menetukan jumlah Produksi buah kelapa sawit, dalam hal ini akan digunakan data jumlah produksi dari tahun-tahun sebelumnya.

\subsection{Analisa Sistem}

Single Moving Average adalah suatu metode peramalan yang di lakukan dengan mengambil data sebelumnya[16]. dalam metode ini mencari nilai ratarata sebagai prediksi atau peramalan untuk periode di masa yang akan datang [17]. Dalam hal ini penelitian menggunakan metode single moving average ini menggunakan data produksi pertahun mulai dari tahun 2015 - 2020, sehingga perlu dilakuan pengolahan data terlebih dahulu sebelum melakukan analisa dengan dengan metode single moving average, pengolahn data ini dilakukan secara manual dari tahun 2015 - 2020 . Berikut data hasil produksi kelapa sawit pada Tabel 1.

\author{
(a)
}

Tabel 1. Hasil Produksi Buah Kelapa Sawit

\begin{tabular}{ccc}
\hline No & Tahun & Produksi (Ton) \\
\hline 1 & 2015 & 225.042 \\
2 & 2016 & 227.456 \\
3 & 2017 & 224.836 \\
4 & 2018 & 217.327 \\
5 & 2019 & 194.066 \\
6 & 2020 & 190.855 \\
\hline \multicolumn{3}{l}{ Jumlah } \\
\hline
\end{tabular}

\subsection{Moving Average}

Dalam menghitung peramalan atau prediksi buah kelapa sawit dengan moving average 3, 4 dan 5 atau rata-rata bergerak 3, 4 dan 5. Menggunakan Persamaan (1). 
$F_{c}=\frac{A_{t+1}+A_{t+2}+\cdots+A_{t-n+1}}{N}$

Dimana $F c$ merupakan nilai peramalan periode $\mathrm{x}_{+1}, A t$ merupakan data aktual periode $\mathrm{x}$, dan $n$ merupakan rata-rata moving average.

Penyelesaian menggunakan single moving average 3 (MA 3) sebagai berikut :

Fc1 $=2015$ total Produksi 225.042 Ton

Fc2 $=2016$ total Produksi 227.456 Ton

$\mathrm{Fc} 3=2017$ total Produksi 224.836 Ton

Fc4 $=2018$ total Produksi 217.327 Ton

$\mathrm{Fc} 4=\frac{A_{t 1}+A_{t 2}+A_{t 3}}{3}$

$\mathrm{Fc} 4=\frac{225.042+227.456+224.836}{3}$

$=225.778$

Fc5 = 2019 total Produksi 194.066 Ton

$$
\begin{aligned}
\mathrm{Fc} 5 & =\frac{A_{t 2}+A_{t 3}+A_{t 4}}{3} \\
& =\frac{227.456+224.836+217.327}{3} \\
& =223.206
\end{aligned}
$$

Fc6 $=2020$ total Produksi 190.855 Ton

$$
\begin{aligned}
\mathrm{Fc} 6 & =\frac{A_{t 3}+A_{t 4}+A_{t 5}}{3} \\
& =\frac{224.836+217.327+194.066}{3} \\
& =212.076
\end{aligned}
$$

Fc7 $=2021$ total Produksi 0

$$
\begin{aligned}
\mathrm{Fc} 7 & =\frac{A_{t 4}+A_{t 5}+A_{t 6}}{3} \\
& =\frac{217.327+194.066+190.855}{3} \\
& =200.749
\end{aligned}
$$

Penyelesaian Single Moving Average 4 (MA 4) sebagai berikut :

Fc5 $=2019$ total Produksi 194.066 Ton

$\mathrm{Fc} 5=\frac{A_{t 1}+A_{t 2}+A_{t 3}+A_{t 4}}{4}$

$\mathrm{Fc} 5=\frac{225.042+227.456+224.836+217.327}{4}$

$$
=223.665
$$

Fc6 $=2020$ total Produksi 190.855 Ton

$\mathrm{Fc} 6=\frac{A_{t 2}+A_{t 3}+A_{t 4}+A_{t 5}}{4}$
$\mathrm{Fc} 6=\frac{227.456+224.836+224.836+217.327}{4}$

$$
=215.921
$$

Fc7 $=2021$ total Produksi 0

$$
\begin{aligned}
\mathrm{Fc} 7 & =\frac{A_{t 3}+A_{t 4}+A_{t 5}+A_{t 6}}{4} \\
\mathrm{Fc} 7 & =\frac{224.836+217.327+194.066+190.855}{4} \\
& =206.771
\end{aligned}
$$

Penyelesaian Single Moving Average 5 (MA 5) sebagai berikut :

Fc6 $=2020$ total Produksi 190.855 Ton

$\mathrm{Fc} 6=\frac{A_{t 1}+A_{t 2}+A_{t 3}+A_{t 4}+A_{t 5}}{5}$

$$
\begin{aligned}
\mathrm{Fc} 6 & =\frac{225.042+227.456+224.836+217.327+194.066}{5} \\
& =217.745
\end{aligned}
$$

Fc7 $=2021$ total Produksi 0

$$
\begin{aligned}
\mathrm{Fc} 7 & =\frac{A_{t 2}+A_{t 3}+A_{t 4}+A_{t 5}+A_{t 6}}{5} \\
\mathrm{Fc} 7 & =\frac{227.456+227.456+224.836+217.327+190.855}{5} \\
& =210.908
\end{aligned}
$$

Dari perhitungan di atas, prediksi buah kelapa sawit menggunakan rata-rata bergerak 3,4 dan 5 menghasilkan jumlah prediksi atau peramalan yang tidak jauh berbeda dari tahun sebelumnya. Berikut Tabel 2 hasil perhitungan menggunakan Moving Average 3, 4 dan 5 menggunakan data 2015- 2020 .

Tabel 2. Hasil Perhitungan Moving Average (Ton)

\begin{tabular}{cccccc}
\hline No & Tahun & Produksi & Ma 3 & Ma 4 & Ma 5 \\
\hline 1 & 2015 & 225.042 & - & - & - \\
2 & 2016 & 227.456 & - & - & - \\
3 & 2017 & 224.836 & - & - & - \\
4 & 2018 & 217.327 & 225.778 & & \\
5 & 2019 & 194.066 & 223.206 & 23.665 & \\
6 & 2020 & 190.855 & 212.076 & 215.921 & 217.745 \\
7 & 2021 & 0 & 200.749 & 206.771 & 210.908 \\
\hline
\end{tabular}

3.4 Nilai Error

Pada tahap mencari nilai error hasil perihitungan ini menggunakan rata-rata bergerak 3, 4 dan 5. Hasil perhitungan nilai peramalan ini sudah dilakukan pada tahap sebelumnya. Pada tahap ini mencari jumlah presentase error yang didapat menggunakan Persamaan (2), (3), dan (4).

$M A D=\frac{|A t-F c|}{n}$ 


$$
\begin{aligned}
& M S E=\frac{|A t-F c| 2}{n} \\
& M A P E=\frac{100 \%}{n} * \frac{|A t-F c|}{A t}
\end{aligned}
$$

Dimana At merupakan permintaan aktual pada periode $x$, Fc merupakan peramalan permintaan (forecast) pada periode $x$, dan $n$ merupakan jumlah periode peramalan yang terlibat.

\section{a. MAD (Mean Absolute Deviation)}

Mean Absolut Deviation (MAD) disebut juga Mean Absolut Error (MAE) merupakan rata-rata kesalahan dalam peramalan selama periode tertentu tanpa memperhatikan apakah hasil peramalan lebih besar atau lebih kecil dibandingkan kenyataannya. Dalam mencari Nilai MAD menggunakan Persamaan 2.

$M A D=\frac{58.812}{3}=19.604$

Hasil yang didapat dari perhitungan error menggunakan Mean Absolute Deviation (MAD) yaitu 19.604

\section{b. MSE (Mean Square Error).}

Rata-rata Kuadrat Kesalahan (Mean Square Error) atau yang lebih sering disebut dengan MSE dapat dihitung dengan menjumlahkan semua kesalahan atau error peramalan pada setiap periode yang selanjutnya dikuadratkan dan membaginya dengan jumlah periode peramalan. Berikut langkah menghitung kesalahan/error dengan mengunakan metode Mean Square Erro).

$M S E=\frac{1.370 .889 .842}{3}=456.963 .281$

Dari perhitungan diatas dapat dilihat bahwa Mean Squared Error (MSE) yaitu 456.963.281

\section{c. MAPE (Mean Absolute Perentage Error)}

MAPE merupakan bentuk persentase dari rata-rata kesalahan absolut. Dibandingkan dengan ukuran sebelumnya, MAPE memiliki makna yang lebih berarti karena MAPE memberikan informasi berupa persentase kesalahan atau error, sehingga kita dapat lebih jelas melihat apakah kesalahan tersebut tergolong tinggi atau rendah. Berikut langkah menghitung kesalahan/error dengan mengunakan metode Mean Absolute Perentage Error.

$$
\begin{aligned}
M A P E & =\frac{100 \%}{3} * 30,0 \\
& =0,333 * 30,0 \\
& =10,0
\end{aligned}
$$

\begin{tabular}{|c|c|c|c|c|c|c|c|}
\hline No & Tahun & Produksi (At) & Ma $3(\mathrm{Fc})$ & Error Fc-At & MAD & MSE & MAPE \\
\hline 1 & 2015 & 225.042 & & & & & \\
\hline 2 & 2016 & 227.456 & & & & & \\
\hline 3 & 2017 & 224.836 & & & & & \\
\hline 4 & 2018 & 217.327 & 225.778 & 8.451 & 8.451 & 71.419 .401 & 3,9 \\
\hline 5 & 2019 & 194.066 & 223.206 & 29.140 & 29.140 & 849.139 .600 & 15,0 \\
\hline 6 & 2020 & 190.855 & 212.076 & 21.221 & 21.221 & 450.330 .841 & 11,1 \\
\hline 7 & 2021 & & 200.749 & & 58.812 & 1.370 .889 .842 & 30,0 \\
\hline \multicolumn{5}{|c|}{ Jumlah Nilai Error } & 19.604 & 456.963 .281 & 10,0 \\
\hline
\end{tabular}

Pada tahap perhitungan Mean Absolute Perentage Error didapat bahwa presentase error hasil peramalan tahun 2021 menggunakan ma 3 adalah $10,0 \%$.

Tabel 3. Hasil Nilai Perhitungan Error MA 3

Dengan Nilai Error Mean Absolute Deviation 19.604,

\begin{tabular}{|c|c|c|c|c|c|c|c|}
\hline No & Tahun & Produksi (At) & $\mathrm{Ma} 4(\mathrm{Fc})$ & Error Fc-At & MAD & MSE & MAPE \\
\hline 1 & 2015 & 225.042 & & & & & \\
\hline 2 & 2016 & 227.456 & & & & & \\
\hline 3 & 2017 & 224.836 & & & & & \\
\hline 4 & 2018 & 217.327 & & & & & \\
\hline 5 & 2019 & 194.066 & 223.665 & 29.599 & 29.599 & 876.100 .801 & 15,3 \\
\hline 6 & 2020 & 190.855 & 215.921 & 25.066 & 25.066 & 628.304 .356 & 13,1 \\
\hline 7 & 2021 & & 206.771 & & 54.665 & 1.504 .405 .157 & 28,4 \\
\hline \multicolumn{5}{|c|}{ Jumlah Nilai Error } & 27.333 & 752.202 .579 & 14,2 \\
\hline
\end{tabular}
Dari Tabel 3 Peramalan Menggunakan Pergerakan 3 Mean Squared Error 456.963.281 dan Mean Absolute atau Moving Average 3 pada tahun 2021 Menghasilkan Percentage Error 10,0\%.

Nilai Peramalan Produksi sebanyak 200.749 Ton,

Tabel 4. Hasil Nilai Perhitungan Error MA 4

Dari Tabel 4 peramalan menggunakan pergerakan 4 dengan Mean Absolute Deviation 27.333, Mean atau Moving Averge 4 pada tahun 2021 menghasilkan Squared Error 752.202.579 dan Mean Absolute nilai peramalan Produksi sebanyak 206.771 Ton Percentage Error 14,2\%. 
Tabel 5. Hasil Nilai Perhitungan Error MA 5

\begin{tabular}{cccccccc}
\hline No & Tahun & Produksi (At) & Ma 5 (Fc) & Error Fc-At & MAD & MSE & MAPE \\
\hline 1 & 2015 & 225.042 & & & & & \\
2 & 2016 & 227.456 & & & & & \\
3 & 2017 & 224.836 & & & & & \\
4 & 2018 & 217.327 & & & & & \\
5 & 2019 & 194.066 & 217.745 & 26.890 & 26.890 & 723.072 .100 & 14,1 \\
6 & 2020 & 190.855 & 210.908 & - & 26.890 & 723.072 .100 & 14,1 \\
7 & 2021 & 0 & & 26.890 & 723.072 .100 & 14,1 \\
\hline \multicolumn{7}{c}{ Jumlah Nilai Error }
\end{tabular}

Dari Tabel 5. Peramalan Menggunakan Pergerakan 5 atau Moving Averge 5 pada tahun 2021 menghasilkan peramalan produksi sebanyak 210.908 Ton dengan Mean Absolute Deviation 26.890, Mean Squared Error 723.072.100 dan Mean Absolute Percent Error 14,1\%

\section{Kesimpulan}

Berdasarkan hasil Perhitungan Peramalan Metode Single Moving Average menggunakan MA 3, 4 dan 5. Maka didapatkan hasil dengan presentase error yang relative Kecil pada MA3 dibandingkan MA4 dan MA5. Dengan Nilai Mean Absolute Deviation 19.604, Mean Squared Error 456.963.281 dan Mean Absolute Percentage Error 10, 0\%. Dan Jumlah Peramalan tahun 2021 sebanyak 200.749 Ton.

\section{Daftar Rujukan}

[1] Dharmawan, A. H., Nasdian, F. T., Barus, B., Kinseng, R. A., Indaryanti, Y., Indriana, H., Mardianingsih, D. I., Rahmadian, F., Hidayati, H. N., \& Roslinawati, A. M. (2019). Kesiapan Petani Kelapa Sawit Swadaya dalam Implementasi ISPO: Persoalan Lingkungan Hidup, Legalitas dan Keberlanjutan. Jurnal Ilmu Lingkungan, 6(2), 304. https://doi.org/10.37676/agritepa.v6i2.879

[2] Aulia, R. U., Harianto, H., \& Novianti, T. (2019). Analisis Posisi Pasar Indonesia Pada Pasar Refined Palm Oil (Rpo) Di Negara Importir. Jurnal Penelitian Kelapa Sawit, 27(1), 1-12. https://doi.org/10.22302/iopri.jur.jpks.v27i1.56

[3] Stephanie, H., Tinaprilla, N., \& Rifin, A. (2018). Efisiensi Pabrik Kelapa Sawit Di Indonesia. Jurnal Agribisnis Indonesia, 6(1), 27-36. https://doi.org/10.29244/jai.2018.6.1.13-22

[4] Efendi, Z., \& Ramon, E. (2019). Peningkatan Produktivitas Kelapa Sawit Dengan Pemberian Pupuk Kompos Dan Biourine Sapi Di Desa Margo Mulyo Kabupaten Bengkulu Tengah. AGRITEPA: Jurnal Ilmu Dan Teknologi Pertanian, 6(2), 29-36. https://doi.org/10.37676/agritepa.v6i2.879

[5] Nurlifa, A., \& Kusumadewi, S. (2017). Sistem Peramalan Jumlah Penjualan Menggunakan Metode Moving Average Pada Rumah Jilbab Zaky. INOVTEK Polbeng - Seri Informatika, 2(1), 18. https://doi.org/10.35314/isi.v2i1.112

[6] Setiawan, D. A., Wahyuningsih, S., \& Goejantoro, R. (2019). Peramalan Produksi Kelapa Sawit Menggunakan Winter's dan Pegel's Exponential Smoothing dengan Pemantauan Tracking Signal. Jambura Journal of Mathematics, 2(1), 1-14. https://doi.org/10.34312/jjom.v2i1.2320

[7] Rachman, R. (2018). Penerapan Metode Moving Average Dan Exponential Smoothing Pada Peramalan Produksi Industri Garment. Jurnal Informatika, 5(2), 211-220. https://doi.org/10.31311/ji.v5i2.3309

[8] Prapcoyo, H. (2018). Peramalan Jumlah Mahasiswa
Menggunakan Moving Average. Telematika, 15(1), 67. https://doi.org/10.31315/telematika.v15i1.3069

9] Putri, A. N., \& Wardhani, A. K. (2020). Penerapan Metode Single Moving Average Untuk Peramalan Harga Cabai Rawit Hijau. Indonesian Journal of Technology, Informatics and $\begin{array}{lll}\text { Science } & \text { (IJTIS), } & \text { 37-40. }\end{array}$ https://doi.org/10.24176/ijtis.v2i1.5653

[10] Anggraeni, D. T. (2019). Forecasting Harga Saham Menggunakan Metode Simple Moving Average Dan Web Scrapping. Jurnal Ilmiah Matrik, 21(3), 234-241. https://doi.org/10.33557/jurnalmatrik.v21i3.726

[11] Hudaningsih, N., Firda Utami, S., \& Abdul Jabbar, W. A. (2020). Perbandingan Peramalan Penjualan Produk Aknil Pt.Sunthi Sepurimengguanakan Metode Single Moving Average Dan Single Exponential Smooting. Jurnal Informatika, Teknologi Dan Sains, 2(1), 15-22. https://doi.org/10.51401/jinteks.v2i1.554

[12] Dewi, E. N. S., \& Chamid, A. A. (2019). Implementation of Single Moving Average Methods For Sales Forecasting Of Bag In Convection Tas Loram Kulon. Jurnal Transformatika, 16(2), 113. https://doi.org/10.26623/transformatika.v16i2.1047

[13] Apriliani, A., Zainuddin, H., Agussalim, A., \& Hasanuddin, Z. (2020). Peramalan Tren Penjualan Menu Restoran Menggunakan Metode Single Moving Average. Jurnal Teknologi Informasi Dan Ilmu Komputer, 7(6), 1161. https://doi.org/10.25126/jtiik.2020722732

[14] Aprilianti, N., Setiawan, I., \& Yusuf, M. N. (2020). Peramalan Permintaan Produk Sale Pisang Pada Industri "Sahabat" Di Dusun Cijoho Desa Margajaya Kecamatan Sukadana Kabupaten Ciamis. Jurnal Ilmiah Mahasiswa Agroinfo Galuh, 7(3), 634. https://doi.org/10.25157/jimag.v7i3.3978

[15] Jaya, J. D. (2019). Peramalan Jumlah Populasi Sapi Potong di Kalimantan Selatan Menggunakan Metode Moving Average, Exponential Smoothing dan Trend Analysis. Jurnal Teknologi Agro-Industri, 6(1), 41. https://doi.org/10.34128/jtai.v6i1.88

16] Bachri, O. S. (2019). Forecasting Jumlah Perkara Perceraian Menggunakan Single Moving Average di Pengadilan Agama Sumber. Jurnal Ilmiah Intech : Information Technology Journal $\begin{array}{lll}\text { of } & \text { UMUS, } & \text { 23-32. }\end{array}$ https://doi.org/10.46772/intech.v1i02.67

[17] Susilawati, D., Setiawan, N., Yulianti, I., \& Prayudi, D. (2018). Penerapan Metode Single Moving Average untuk Prediksi Penjualan Pada Aby Manyu Cell. Swabumi, 6(1), 78-84. https://doi.org/10.31294/swabumi.v6i1.3319

Jurnal Informasi dan Teknologi Vol . 3 No. 4 (2021) 251-256 